ANADOLU HALK EZGILERINDE KARAR VE PERDE DERECELERININ ÖNEMINDEN HAREKETLE SINIFLANDIRILMASI IMPORTANCE OF DECISION AND PITCH DEGREES İlhami KAYA*

Geliş Tarihi: 21.01.2021

(Received)

\section{öz: Makam} sınıflandırma bakımından farklı yaklaşımlarla birlikte açıklamalar ihtiva eder. Farklı anlayışlar ihtiva eden bu çalışmaların tümü bir külliyat oluşturur. İçeriklerinde yer alan farklılıklar belli anlayışın ya da ekolün (Pisagorcu, Sistemci Okul vb.) modeline karşılık gelir. Modeller incelendiğinde içerisinde değişik atılımların ve yaklaşımların olduğu görülse de sürekli artan bir makam ve terkip kavramları ile karşı karşıya kalınmaktadır. Halk müzikleri ise herhangi bir kurama bağlı olmayan yapıları ile dikkat çeker. Genellikle âşık ya da ozan adı verilen kişilerce irticalen tasarlanan ezgiler içerir. Bu nedenle ezgiler içerisinde kullanılan perdeler yardımı ile ortaya çıkan sıralı perdeler (cins, makam ya da diziler) halk tarafindan verilen geleneksel isimler (ayak) dışında konu üzerine çalışmaları olan uzmanlarca (makam) tanımlanmaktadır. Fakat bu tür çalışmalarda ortak bir yöntem ya da metot kullanılmadığı gibi kuramsal temellerinin de tarihsel açıdan ele alınmadığ görülmektedir. Günümüzde ise makam ve ayak konusunda Halk müziği üzerine yazılan (makale, kitap, sempozyum vb.) ya da söylenen birçok çalışma mevcuttur. Halk müziği çalışmalarında ortak fikir olarak temel alınan ayak konusu olsa da bazı konularda makam olduğu öne sürülen farklı görüşlerin olduğu bilinmektedir. Bu çalışma; her iki görüşten hareketle farklı bir yöntem kullanılabileceği gibi göz ardı edilen yönlerin eksikliklerini ortaya koymayı hedeflemektedir. Çalışmada literatür taraması ile birlikte halk müziği örneklemlerinde gösterilen ve bugünde çalgılarda kullanıldığg düşünülen perde analizlerine yer verilmiştir. Analizler için bugüne kadar kayıt altına alınmış ve Türkiye Radyo Kurumu (TRT) arşivlerinde yer alan tam olarak üç bin sekiz yüz seksen bir halk ezgisinin notası temel alınmıştır. Analiz edilen eserlerde genellikle belli bir diziyi ele alan sözlü ve sözsüz eserler bir arada ele alınmıştır. Çalışmanın yöntemi halk ezgi örneklemleri ele alınarak incelenen eserler belirli bir perde sırasına göre sınıflandırmaktır. Çalışma kapsamında TRT halk müziği repertuarına göre performans örnekleri ile birlikte analiz edilmiştir. Analizler başlangıçta karar perdelerine dayanılarak yapılmış ve karar perdesine göre ses perdeleri pes taraftan tize doğru sıralanmıştır. Çalışmada kullanılan perdeler daha sonra karar perdesi temel alınarak herhangi bir değiştirici işaret (diyez veya bemol) alıp almadıklarına

*Doç. Dr., Batman Üniversitesi, ilhami.kaya@batman.edu.tr, ORCID:0000-0002-18313828 
bakılmaksızın derecelendirilmiştir. Tanımlanan örneklerin daha ileri sınıflandırmalar için genel bir fikir ortaya koyacağı tahmin edilmektedir.

Anahtar Kelimeler: Ayak, Makam, Dizi, Halk Müziği ve Halk Müziği Repertuarı ABSTRACT: In maqam terms, theoretical studies from the ninth century up to the present in the theoretical context contain explanations with different approaches in terms of classification. Containing different insights, all studies constitute a collection. The differences in their contents may correspond to model of a particular understanding or ecole (Pythagorean, Systemist School, etc.). When the models are examined, it is seen that there are various initiatives and approaches, but there is a constantly increasing concept of maqam and composition. Folk music takes attention with its structures which are not connected to any theory. It usually includes melodies designed by people who are called âşı or bards. For this reason, apart from the traditional names given by the public (as ayak), the sequential pitch (type of maqam, maqam or scale) that emerge with the help of the pitch used in the melodies are defined by the experts (as maqam) who have studies on the subject. However, it is seen that a common method is not used in such studies and that the theoretical fundamentals are not discussed in a historical perspective. Today, there are many works written or said on folk music (articles, books, symposiums, etc.) about the maqams and ayak. Although the subject of ayak is taken as the common idea in folk music studies, it is known that there are different opinions which are suggested to be the maqam on some subjects. In the study, along with the literature review, pitch analyzes shown in folk music samples and thought to be used in instruments today are included. The analyses were based on approximately four thousand recorded folk notes (possessing lyrics or not) from the archives of Turkey Radio Corporation (TRT). The method of the study is to classify the analyzed works according to a certain pitch order by considering folk melodies samples. The scope of the study covered TRT folk music repertoire and analyses were carried out with the performance samples based on all provinces rather than the regions. The analyses have been initially based on tonic pitches, and a classification was made by ignoring the high or low pitches which were sorted in a sequence according to the tonic pitch. The pitches used in the work were then graded and checked to see if they took any changers (sharp or flat). It is anticipated that the described examples will provide a general idea for further classification.

Key Words: Ayak, Maqams, Scale, Folk Music and Folk Music Repertory

\section{EXTENDED ABSTRACT}

People who make folk songs living in Anatolia until today have created melodies by acting with a tradition rather than a theory. For this reason, melodies can be seen in similar motifs or patterns, rhythms, words or subjects belonging to various communities. It is seen that there are aspects that can be looked at in composition today, apart from the fundamentals of impromptu practice of folk melodies in Anatolia. However, when this understanding of composition is examined with the aspects accepted by the public, it acts with a master-apprentice relationship. For this reason, it can be said that the old tradition of a community is hidden in new creations with different melodies.

Final voice is of great importance that attract attention in the first of the structures which is in the examinations made on the examples of folk melodies in Anatolia. Due to the 
different final voice it has been determined that the second structure moves over the tuning and different tuning. Due to having different tuning, the works are shaped with the timbre or colors used with the help of the attitude (beat patterns of plectrum). These beat patterns of plectrum are not only local but also personal. It is thought that the works shaped by different tuning and beat patterns of plectrum have the same pitch sizes. However, the size of pitches made of maqam, ayak or scale formed by the sequential pitch will differ in pitch degrees. This situation is not disturbing sensory and it can also allow different timbres together with different tuning made for works. However, this situation will not explain the reason for using different tuning and the relationship of different tuning with certain maqams. For this reason, the maqam, ayak or scale will contain differences according to the different tuning made. Thus, maqams, ayak or scales with the same pitch sizes will form different sets within themselves.

The differences in Anatolia folk melodies show themselves not only in the pitches used, but also in the order (different of chord) used. For this reason, although the pitch in the scale in question suggest that a previously known maqam is şeddi (recessed), it is seen that some of the pitch differ in their use according to the degrees of the main scale pitches. For example, the maqam of kurdilihicazkar, which is the wall of a hicazkâr work and decides on the pitch of rast; It is seen that the use of the hicaz pitch together with the kurdi pitch is more important than the pitch grades used in the main makam. For this reason, the strong pitch of the maqam may be of the third degree, and it suggests that more importance is given to the pitches that provide changes in its use. Thus, the importance of naming the makams with a single pitch and the importance of this pitch is particularly emphasized.

In maqams are not thought to be effective (a secondary change on same pitch degree), which are thought to be temporary in addition to pitch and type of modes. However, all the different orientations will clearly reveal its difference from modal music that it will make in the same work will give the under maqams of this maqam. Therefore, the basis of the study has been the search for an analysis model that can be made by including all the varying pitches. But in this direction, the aim of the study is to reveal how folk melodies are completely ignored in maqam music, how they reflect the maqam characteristics without the need for any theory. For this reason, although the reasons for this were tried to be explained in addition to examining it under three headings as maqam, ayak or scale a proposal was presented without including the discussions on the subject.

As a result of the analysis, it was determined that there was no consistency in the number of pitches as well as the use of different pitch among the difficulties encountered. For this reason, since a single explanation is needed, it has been thought that the pitch degrees and variables as maqam, ayak or scale can be included in a common classification. Firstly, the decision pitch, then their numbers and then the pitch degrees with the varying pitches were determined. Then, the changed pitch degrees and samples were examined and evaluated in two different classes. 
Contrary to the makam music, folk melodies have many works that are not eight and can be considered as a single type of mode. It should not be forgotten that there are examples in these works that show that the şed makams can be expressed in different decision pitches, as well as in different eight scales that can be considered simple in makam music today. For this reason, it is thought that all pitches and their variables have an equal importance in order to draw a conclusion from the analysis. In this direction, it has been seen that the variables that change together with the previously determined and determined pitches can be classified from the pitch grades. With this aspect, the study differs from other studies and also reveals its importance. In folk melodies, other than the use of şed makams, which are described or shown in makam music, there are examples of different decisions. Especially in fixed-fret instruments such as baglama, it becomes a tool to understand the maqam and structure. For this reason, the execution of different tuning in the same decisions is also examined.

Each of the pitches used in the works can be the decision pitch of another work or it can be a strong pitch. For this reason, it can be thought that the emphasis of words will make this a determining feature. However, it will be seen that dance figures will be decisive in nonverbal works. In this case, when the works using the hanging decision are ignored, it will be seen that the first change in the works using the same pitch is made in the degree of the strong pitch. Then the other pitchs and pitch degrees changes will be seen. The second change will be in the directions of the expansion parts and the pitches used. Since the change of the strong pitch, the differences in the expansion parts and their directions will affect the maqam as a whole, attention has been paid to the analysis.

Even if the strings containing pitch that can be considered close to each other are ignored as a method, they are also considered as the sizes of the same type of mode from different pitch. For this reason, it has been determined that the type of mode have size differences both in different pitches and within themselves. In these analyzes eight works, which were structured on the basis of type of mode and strong pitches, based on the methods used by theorists before, were also examined. At this point, the first differences were seen that the strong pitch are the third, fourth, fifth and sixth frets of the pitch that make up the scale. Secondly, the existence of undefined simple makams in the makam

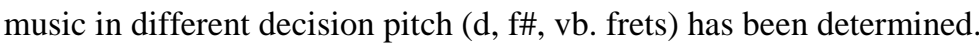

As a result, since there may be examples where each curtain can be strong in unmeasured air, the studies were carried out on measured air. Detected; With the structuring of different type of mode, it was concluded that the type of mode could start from at least two pitch and reach more than three, four, five and six pitch. Secondly, in the analyzes to be made with the decision pitch and the pitch degrees, it will ensure that the curtain and its variables are gathered under a common roof. In this way, the features of the works can be revealed as well as they can be compared over different decision pitch. For this reason, although the sequential pitch sizes in different decisions are thought to be the same sensory, they differ in pitch sizes and strength, movement, etc. It has been determined that it continues in other makam characteristics as well. This proposal is based on some 
findings in the literature and based on a certain principle which firstly decision pitch then then it was done by grading the determined pitch degree. It is thought that a classification in this way will enable us to reach the antecedents of the makam, as well as update the features of the makam.

\section{GİRIŞ}

Makam kuramı üzerine yapılan çalışmalara bakıldığında; bazı tanımlamaların dokuzuncu yüzyıl öncesinden başlanarak bugüne dek sürdürüldüğü görülmektedir. Tanımlamalarla birlikte on altıncı yüzyıl sonrasında müzik eserlerinin müzik yazısı ile kâğıt üzerinde belli sembollerle ifade edilmesine çalışılmıştır. Son 100-110 yıl içerisinde müzik yazısı (Behar, 2019: 22) ile kayda alınan örneklerin bugünün repertuarını oluşturduğundan kayda alınanlar içerisinde Halk müziklerinin de yer aldığı görülür.

Kuramsal açıdan Halk müziği terminolojisinin son dönemlerde yetersiz olduğu düşünülse de yapılmış çalışmalarda kullanılmayan metotların izlenilmesi gereken eksikleri tamamlamaya bir adım olarak görülebilir. Rauf Yektâ Bey'in 1898 ve 1899 yıllarında İkdâm gazetesine yazdığı yazılarda (Deniz, 2018: 256257), türkülerin müzik yazısına alınarak yayınlanması konusunda atılımları bulunsa da ilk derleme, toplama ya da tasnif çalışmaları Musa Süreyya yönetiminde gerçekleşmiştir (Yönetken, 1982: 5). 1916 yılında kurulma çalışmalarına başlanan ve 1917'de resmi olarak kurulan Darülelhan'ın kurulumunun ardından (Kolukırık, 2014: 486-488) ilk resmî derlemelerin 1923-1926 yılları arasında yapıldığı bilinse de (Özdemir, 2019: 2133) resmi anlamda ilk derleme çalışmasının bugün "Yurdumuzun Nağmeleri" adlı kitap olarak durmaktadır (Kolukırık, 2012: 802). $\mathrm{Bu}$ tarihlerden itibaren derleme çalışmaları 1967 yılına kadar kurumsal olarak sürdürüldüğ̈̈ (Eke, 2016: 38) bireysel çalışmaların hala sürdürüldügü bilinmektedir. Bu açıdan derlemeler; yalnız sözlü ya da sözsüz türküleri kayıt altına alma çalışmaları olmasının yanı sıra kullanılan terimlerin yapılacak olan disiplinin terminolojisine katkı sağlayacağı düşünülebilir. Bunlar dışında Bela Bartok (Sipos: 2000: 10), Hubert Pernot ve Felix von Luschan gibi yabanc1 etno-müzikologların da ülkemiz ezgilerini fonograf ile kayıt altına aldığı çalışmalar ayrıca incelenmesi (Yavuz-Tahtaişleyen-Önder, 2020) 19-98)gereken kayıtlar olarak görülebilir.

Aktarım ve öğretim olarak Halk müziklerinde üsluplar, tavırlar ya da diğer yapıları usta-çırak ilişkisi içerisinde ilerleme kaydetmiştir. Ezgiler ya da tavırlar, yazılı olmaktan çok, istek, beceri ve hafıza sayesinde yaşatılarak bugüne kadar getirilmiştir. Sözlü bir kültür ürünü olan halk ezgilerinin yayılımı (Özbek, 1994: 64), âşı ya da ozanın müzikal hafızasına veya kültürüne bağlı olarak gelişme gösterir. $\mathrm{Bu}$ açıdan hafiza merkezli olan bu eğitimin (usta-çırak) bulunduğu alan ile 
birlikte bir başka yere taşınır olması ve değiştirilerek ya da çeşitlenerek geliştirilebilir olması Halk ezgilerini anonimleştirerek bir millete özgü kılmıştır.

Derleme notalarına bakıldığında; müzik yazılarında daha sonraları değiş̧iklikler yapıldığı görülmektedir (Güray, 2017). Bununla birlikte yeni perde değerlerinin yahut eklemelerin yapıldığı bilinmektedir (Özdemir, 2019: 2135-6). Bu değişimler müzik yazısında olduğu gibi (Behar, 2019: 124-141) bugünkü icrada kullanıldığı açık bir şekilde görülmektedir. $\mathrm{Bu}$ perde değişiklikleri kişisel becerilerden ve çalgı tınılarından da kaynaklanabilir. Bu durum; temel olarak belirlenen perdelerde yapılacak değişikliklerin, herhangi bir makam ya da ayağı duyumsal olarak etkileyip etkilemeyeceğine dair tartışmalara neden olacaktır. Özellikle Aydın yöresine ait olan "Bozdoğan Türküsü̈"nde olduğu gibi İsmail Hakkı Bey Mûsiki Tekâmül Dersleri adlı kitabında yaptı̆̆ı tarife göre bu dizi; hem Arap hem de Türk Çargâhının (Kaygusuz, 2006: 37) özelliklerini taşıdığı düşünülecektir. Eserde ele alınan si ve sib2 perdesinin iki farklı makamın birleşimi olarak dursa da karar perdesinin belirleyiciliği verilecek olan sonuçta etkin olabileceğine işaret edebilir.

Batı müziği kuramında akustik temelli aralık yahut perdelerin, Antik Yunanda Pisagor ve Pisagorcularla birlikte sayı ya da oranlar esas alınarak tanımlandığı bilinmektedir. Makam müziğinde ise aynı gelenek Antik Yunan metinlerinin tercümesi ile El-Kındi (801-873), Farabi (873-950) ve İbni Sina (9801037) ile birlikte Urmevi gibi (1217-1294) vb. düşünürlerin ele alış biçimleri perde ile birlikte aralıkların sayı ya da oranlarla tanımlamasını mümkün kılmıştır. Sistemci okul olarak anılan bu grubun bakış açısının yirminci yüzyılda Rauf Yekta (1871-1935) ve sonrasını etkileyerek devam ettiği görülmektedir. Böylelikle ortak bir terminolojide Makam müziğinin de ifade edilmesi mümkün kılınmıştır.

Osmanlı döneminden bu yana tıpkı Halk müziklerinde olduğu gibi usta-çırak metodu ile sürdürülen makamsal müzik geleneğinde makam tanımının; ilk kez on beşinci yüzyılda Abdülkâdir Merâgî (1360-1435) tarafından kullanıldığı düşünülmektedir (Kaçar, 2008: 148). Abdülkadir Merâgî dönemine dek makamlar sedd, devir vb kavramlar ile tarif edilse de neredeyse tüm kaynaklarda karşılaşılan makam kavramının farklı biçimde tanımlanmış olduğu görülür. Bu durum; daha sonraları makam nazariyesi üzerinde çalışan Abdülbaki Nasır Dede tarafindan "musiki nazariyat dönemi” adı altında açıkça vurgulanmıştır. “... Edvar-ı ezman, ebu'l hukema Fisagoras hâkime reside oldukda, hâkimi mezkûr kuvvet-i riyazat ile bu ilm-i musikiyi ihtira eyleyüb, kavanin-i külliye bast eyledi. Badehu, hukemadan Aristo[zen] ve Farabi, vesairlerinden Şeyh Safiyüddin Abdülmümin gibi, irtiyaz ve telahukk-ı efkar ile ziyade eylediler. Fe-amma akdemunun usul-i elhandan tertibat başkadır (müellifin notu: Bu mahalde usul-i elhandan murad, niseb-i mabeyn-i negamat ve aksam-ı zi'l-erba ve aksam-ı zi'l-hamsedir ). Ve kudemanin oniki makam, altı ve bir rivayetde yedi avaze, yirmidört şube ve terkibatı 

bazısinı tard ve yerine yine matrudun ismi ile avazeden ve kendi muhteralarindan ahz ve bakisinde başka itibarlar eylediler ve bu evza üzre yedi avaze ve dört şube ve terkibat-l adide itibar ve ihtira eylediler" (Yarman, 2009: 3).

Nazariyatçıların bu farklı yaklaşımlarından dolayı edvâr kitaplarında makâm, âvâze, şûbe ve terkîb gibi terim tanımları, isimleri ya da sayıları ile birlikte açıklanmasına rağmen, bu terimlerin aynı isim ya da sayı ile verilmediği görülmektedir. Dönemlere göre terimlerin bazıları için yapılan tanım ve isimlerin zamanla değiştiği görülmüştür. Ayak konusunda ise yapılan tanımlamaların genellikle yirminci yüzyılda derleme çalışmalarının ardından olduğu görülmektedir. Bununla birlikte birden fazla anlamının olması, halk ezgilerinde yer alan dizilerin adlandırılması açısından önemli bir problem oluşturmaktadır.

\section{MAKAM VE AYAK KONUSUNDA TESPIT EDILEN TEMEL} EKSIKKLIKLER

Makam; kavramsal olarak birçok tanıma sahiptir. On beşinci yüzyıldan itibaren edvar yahut risale benzeri kaynaklarda karşılaşılan tanımlamaların ötesine geçememiştir. Yapılan tanımlar üzerinden hareket edildiğinde ortak görüşün temeli; karar perdesi, belirli kurallar çerçevesinde cinsler yardımı ile dizisi, güçlüsü, seyri gibi bazı özellikler içermesidir. Buna rağmen kuramsal olarak makam müziklerinde makamları ifade eden tek bir tanım hala mevcut değildir. $\mathrm{Bu}$ nedenle aynı makam gruplarında yer alan tüm makamsal eserlerde ezgilerin kullanılan perde değerleri, usulü, kullanım biçimi (şark1, semai vb.), seyri, muhtemel ikincil durakları, güçlüsü (güçlüleri) ve genişleme kısımları dâhil tüm perdelerinde geçici olarak aldığı değiştirici işaretler temel alınarak ortak bir tanımlanma yapılması mümkün olacaktır. Böylelikle makamın tüm özelliklerini öğreneceğimiz gibi farklı ifade edilmesinin nedenleri ayrıca incelenmesi gereken konular arasinda yer alacaktır.

Makam, Arapça kökenli kâme fiilinden türemiş, ayaküstünde durmak, kalkmak, dikilmek, yükselmek, kaldırmak, dikmek gibi anlamlar taşımaktadır. Aynı kökten, Türkçe'de kavim (akvâm), kayyûm, kıyâm, kıyâmet, kâ'im, ikâme, ikâmet, istikâmet, takvîm, takâvim, mukâvemet gibi kelimelerde kullanılmıştır (Kaçar, 2008: 145). Halk müziği içerisinde sıralı perdelerin oluşturduğu dizi kalıpları ise daha önce Rauf Yekta tarafindan 1923 yılında yayınlanan "Anadolu Halk Şarkıları" adlı türkü defterlerinde olduğu gibi (Deniz, 2018: 260-264) kuramcılar tarafından tanımlanan makamlardan farklı olarak sonrasında "ayak" adı ile ifade edildiği görülmektedir. 


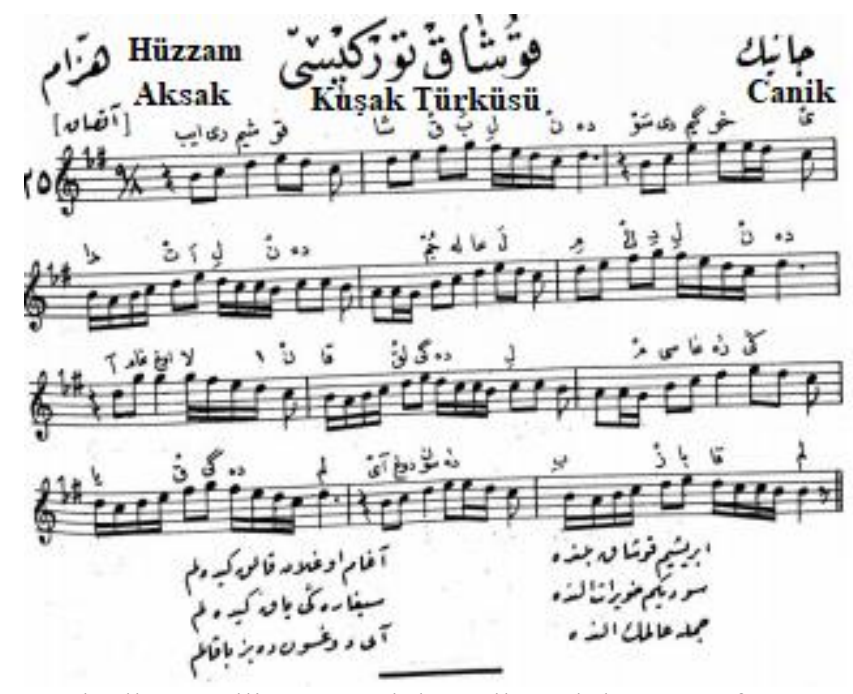

Resim 1. Dârü'l-Elhân Külliyatı Anadolu Halk Şarkıları 1. Defter, 1926: 13.

Ayaklar, diziler dışında halk müziğinde farklı anlamlar da ihtiva etmektedir. Buna rağmen ayaklar makama karşılık ifade edilse de günümüzde kabul görmemiş bir tanım olarak yer almaktadır. (Yener, 1991: 340). Ayak kelime anlamı itibariyle "herhangi bir şeyin yere basan ve üzerinde durduğu bölümü" olarak tanımlanmasına rağmen "kâfiye vermek, karâr perdesi, yer, zemîn, kalıp ezgi" gibi anlamlarla da ifade edilmektedir (Karaduman, 2014: 589). Bu tanımlar dişında ayak hakkında birçok tanım mevcut olmasının yanı sıra aynı bölgede farklı anlamlarda da (halk edebiyatında) kullanılabileceğini göz ardı etmemek gerekir. Tüm bunlarla birlikte ayak kavramını makam ile bağdaştıran alan uzmanlarının yanı sıra dizi olarak ayrıca tanımlanmasını düşünenler yer almaktadır (Arel, 1991: 49).

Ayakların bir makam dizisine karşıllk olduğu konusunda da yaygın bir fikir vardır. Bu nedenle kimi zaman âşık makamları olarak da ayrıca adlandırılmalarının yanı sıra gelenek mensubu kişilerce kullanıldığı bilinmektedir. Fakat yaygın olarak günümüzde "âşı makamları yerine hava terimi" kullanılmaktadır (Tutu, 2012: 99). Bu nedenle havalar içerisinde de farklı adlandırmalar söz konusudur. Bununla birlikte makam kavramının, "âş̧ı müziğinde kullanılan makam kavramları arasında farklılıkların" olduğu görülmektedir (Sümbüllü, 2015: 829). Gelenek mensubu kişilerce makam olarak adlandırılan ezgilerin bugünkü makam tanımlarına uygun düşmeyen yönlerinin olduğu tespit edilmektedir. Hatta "usul değişikliklerinin dahi" bu tür ezgilerin başka bir makam olarak adlandırılmasına neden olduğu düşünülmektedir (Karabulut, 1995: 56).

Makam ve ayak konusunda yapılan tanımlamalara göre ortak noktalarının olduğu söylemek mümkün olsa da yapısal farklılıkların unutulmaması 
gerekmektedir. Buna karşın ortak makam ve ayakların olduğunu da göz ardı etmemek gerekir. Bu nedenle çoğu Anadolu'da icra edilen Türk Osmanlı müziği ile Halk müziği eserlerini belirli bir makam olarak tanımlamak mümkün olsa dahi terminolojik yetersizlik ve yapısal analiz eksikliği bugüne kadar genel bir tanımlama yapılmasını mümkün kılmamaktadır.

Günümüzde makam müziğinde temel alınan dörtlü ve beşli cinslerin ezgisel birleşimleri ile elde edilen sekizli örgütsel perdeleri esas teşkil eder. Makamları tanımlamak için birçok modelin kullanıldığ bilinmektedir. Kullanılan yöntemlerin farklı oluşu, bazı modelleri tespit etme olanağı sağlamaktadır (Öztürk, 2014: 7). Bu modeller; birer kaynak olarak teşkil edilse de devamlılığı ve sürekliliğine bakıldığında değişimlerin olduğu söylenebilir. Bu nedenle biri diğerinin devamı olmanın yanı sıra nazari farklılıklarını ve makamsal (makam, cins isimleri ile birlikte sayılarının) ifade farklılıklarını beraberinde taşımaktadır.

Halk ezgilerinin temel kavramlarına bakıldığında ilk olarak halk tarafindan tarif edildiği daha sonrasında tariflerin eksik ya da yetersiz olsa da halk ağzı ile akademik bir dil kazandığı görülür. Bu tür benzerlikler analizler yardımı ile bulundukları yerler hakkında fikirler öne sürmemize geleneği anlamamızı sağlar. Yöntem olarak kullanılan usta-çırak ilişkisinde makam yahut ayakların yanı sıra düzen ve akort farklılıklar analiz farklılıkları olarak ayrıca incelenmesi gereken veriler olarak tartışılabilir. Bu açıdan kayıtlar ya da müzik yazıları için Batılı veya yerel müzik insanlarının çabaları ile sınıflandırmaların yalnız yörelere göre yapıldığı (icra açısından fikir veren önemli bir yaklaşımdır) yapısal herhangi bir analizin yapılmadığını düşündürmektedir. Eğitim kurumları daha önceleri bir usta yardımı ile üslup, tavır ya da terminoloji hakkında bilgi sahibi olmuştur. Bu açıdan bakıldığında yapılan çalışmalar her ne kadar eksik ya da yetersiz olsa da tarif edilen temel terimler dayanak noktasını teşkil etmektedir.

Bugün Anadolu halk ezgileri için kullanılan tanımlamalara bakıldığında; âşıklar ve ozanlar dişında uzmanlarca yapılan isimlendirmelerle devam ettiği görülmektedir. Konu özelinde ortak bir noktanın olmaması temel nedenleri arasında tıpkı Türk Osmanlı müziğinde olduğu gibi Halk ezgileri için bugüne kadar yeteri kadar yazılmış herhangi bir edvar ve risale benzeri kaynakların bulunmaması gibi durmaktadır. Bunun dışında Makam müziği kuramına göre incelendiğinde bazı eserlerin yalnız üç, dört, beş, altı yahut yedi perdesinin kullanılması bir makam olup olamayacağını tartışılır kılmaktadır. Temel soru yapılan tariflere göre makamların tüm özelliklerinin genel olarak sağlama şartının olmamasındandır. $\mathrm{Bu}$ nedenle yalnız konu uzmanlarının görüşlerinden hareket etmenin yanı sıra analizlere yardımcı olabileceği düşünülen diğer noktalar ayrıca işaret edilmeye çalışılmıştır. 
Halk müziklerinde ezgiler genel olarak ayak, makam ve dizi olarak üç ana başlıkta değerlendirilse de tam karşıllı̆ını bulamadığı üzerine yapılan tartışmalarla görülmektedir. Bunun temel nedeni; ezgileri yapan yahut türkü yakıcılar olan âşık, ozan vb. kimselerin ayak, makam ve dizi gibi kavramları düşünmemesidir. Buna rağmen halk ezgilerinde; tıpkı makam müziklerinde ele alındığ 1 bir biçimde tarif edilmiş cins ya da makam tarifi olmasa da içerisinde buna benzer yapıları bulmak mümkündür. Fakat tam karşılığı olmayan örneklerin de ayrıca ele alınıp incelenmesi gerekmektedir. $\mathrm{Bu}$ temelde makam müziği üzerine yapılan çalışmalarda daha önce kullanılan terimler karşılık bulsa da bulmayanlar için yeni bir dile ihtiyaç duyulabilir.

Halk türkülerinde ezgi kalıbı ya da belirli bir ezgi üzerinde seyri makamın kendisi olup olmadığı tartışılan bir konudur. Bunun dışında yapılan geçici değiştiricilerin hiçbir etkisinin olmadığını, güçlülerinin farklı perdelerle ifade edilmesinin yanı sıra iki farklı güçlü perdesini kullanılabilir olması ve farklı genişleme alanları ile yönünün olmasının yanı sıra genişlemelerde farklı cinslerin varlığı analizlerin yapılmasını açık kılmaktadır. Bu açıdan Anadolu'da bulunan tüm ezgiler makamı tarif etmede bir söz sahibi olabilir. "Halk bestekârları makam- hususunda kendilerini bir takım ilmî kuyût ve şuyût ile bağlamadıkları gibi ika' cihetini de gelişi güzel müsamaha etmişler, hatta iki satırlık küçük bir şarkıda birkaç-makam-ve-ika'- değiştirmeyi bile caiz görmüşlerdir. ... Bunların içinde bazan -makam itibariyle- sabit bir rengi olmayan bazl şarkllara da tesadüf ettik $k i$ bunlara -filan makamdandır- demek mümkün olamadı" (Gazimihal, 2006: 84). Bunun temel nedeni ise ilk olarak makam tanımlamalarında halk ezgilerinin göz ardı edildiğini düşündürmektedir. Bugünkü yapılan çalışmalar bunların birer avaze, şube ya da terkip olması düşünülse de yetersiz kaldığı düşünülmektedir. "...âvâze ismi sekiz, beş, altı sesten husule gelenlere konulmuştur; misal olarak bu müellifler [eski nazariyeciler] bizim bu günkü rast dizimizi gerdaniye namile âvâzeler arasında yazmışlardır; mülayim ve müstakil olan bu diziyi on iki makamları sirasında söylemeyüpte âvâzeler arasinda bahsedişlerinden onların indinde makam ile âvâzenin hususiyetleri olmadiğı anlaşıllyor ..." (Ezgi, 1940: IV: 189). Âvâzelerin birer makam olmadığ 1 yalnız sistemci okul tarafından beste aracı olarak kullanıldı̆̆ bilinmektedir (Kutluğ, 2000: 39, 41).

Halk ezgilerinde kullanılan diziler farklılık gösterip belli bir sayıya sahip değillerdir. Bu nedenle üç perdeye sahip halk ezgilerini bir makam ya da ayak kavramına dâhil etme kesinleşmiş bir konu olarak durmamaktadır. Eski nazariyat temelinde makamlar; bir sekizli daire ya da dizi oluşturulması esas teşkil etmiştir. Fakat oluşum tarzlarında bir düzen içerisinde makamlar, bir sekizli daire ya da diziden ziyade, bağlı bulundukları düzen veya ezgi hareketlerine bağlı olacağını düşündürmektedir. Temel olarak alınan ise ses genişliklerinin bir düzen ya da ezgi hareketine bağlı olup olmadığıdır. Bu nedenle bazı makamların yalnız üç perde ile 
bazılarının ise sekizli aralığı aşabilecek sınırlılıkla olabileceği düşünülmektedir. $\mathrm{Bu}$ durumda dikkate alınan, makamın düzenidir (Öztürk, 2014: 41).

Halk müziklerinde düzen yapılacak olan akorda eş değer olduğundan ortaya çıkan makamların her birinin, bir başka düzende duyum açısından benzer olabileceği görülebilir. Bozuk düzen üzerinde sol ya da re karar perdesine sahip çoğu eser bazı makamların icrasına imkân verse de diğer düzenler üzerinde (misket ya da do müstezat düzeninde hüseyni makamının icrası gibi) bu tür icraların doğru bir şekilde ifade edilemeyeceği bilinir. Bu nedenle her makam tüm düzenlerde icra edilemeyeceğinden düzenlere uygun makamların varlığı söz konusu olabilir. Halk ezgileri belli bir kurama tabii olmadıklarından kullanılan ezgilerin de belirlenmiş bir kuram üzerinden hareket etmediği görülmektedir. Karar perdelerinin farklı olması bir yana tek bir noktadan hareketle tüm diziler tanımlamak mümkün olmayıp düzenler ve uygulanan farklı akort sistemleri ile ifade edilmektedir. $\mathrm{Bu}$ düzenlerin belirli bölgelerce kullanımı kişiye özgü olarak değerlendirilebilir. Bunun dıșında TRT repertuarına bakıldığında bazı eserlerin ise iki sesli olarak da kayıt alındığı bilinmektedir (Sarısözen, 1944: 6). Bu tür iki ayrı partide yazılmış eserler Tunceli dişında Erzurum ve Erzincan örneklerinde rastlamak mümkündür. Analizler sırasında müzik yazısında dikkate alınacak olan eserin bütünü olacağından belirlenecek düzen makam, ayak ya da dizi konusunda bizlerin fikir sahibi olmasını sağlayabilir.

Makam ya da ayak olarak tanımlanamamasının sebepleri sıralanacak olursa; analizlerde ilk olarak eserlerin belli bir dizi sıralanışına (cinslere) tabii olmaması gelmektedir. Bu nedenle iki perde ile birlikte üç, dört, beş, altı, yedi ve sekiz perdeli örnekler bulunmaktadır. Osmanlı müzik risaleleri ya da edvarlarında makamlar konusunda dikkat çeken iki perde ile birlikte üç, dört ve beş perdeli yapıların da değerlendirilmesidir (Öztürk, 2014: 113-114).

İkincisi, analizlerde belli bir dizi sıralanışı olsa dahi ezgisel hattın çizdiği yapıda güçlü perdesinin derece olarak üç, dört, beş ve altıncı perdelerinin yanı sıra bazı eserlerde iki ve yedinci perdesinin de güçlü özelliği gösterdiği düşünülmektedir. $\mathrm{Bu}$ nedenle her birinin göçürülmüş ya da bir bileşik makam olduğu söylenilse de farklı kararlar yer alan örnekler göz ardı edilmemelidir.

Üçüncüsü aynı perdelere sahip eserlerde yeden perdesinin yarım, tam ve kuramda olmasa dahi analizlerde çeyrek perdeleri kullandığ 1 yahut hiçbirini kullanmadığ 1 tespit edilmiştir.

Dördüncüsü; genişleme kısımlarının belli bir sayıda perde kullanmaktan ziyade farklılık göstermesinin yanı sıra her iki yönde de genişleyen ve eksik genişlemelerin olduğunu gösteren örneklerin varlığ 1 söz konusudur. Bunlar dışında karar perdelerinin sahip olduğu perdelere göre iki, üç, dört ya da beşinci 
perdelerinde esas karar perdesi yerine asma karar kullanılan örnekler de ayrıca mevcuttur.

Makam ifadesi âşıklık geleneğinde ilk olarak 1946 yılında Pertev Naili Boratav'ın Halk Hikâyeleri ve Halk Hikâyeciliği adlı kitabında rastlanır (Sümbüllü, 2015: 830). Bu dizilerin ezgisel hareketinden yola çıkılarak makam olup olmadığının tespiti belirlenecek olan kıstaslarla sağlanabilir. Makam, belirlenmiş perdeler üzerinde belli bir ezgi kalıbı örneğinin seyrine göre yapmış olduğu hareketi olarak da tanımlanmaktadır. Bir anlamda makam bu tür ezgi kalıplarından hareketle yapılan seyir biçimidir (Zeren, 2003: 95). Fakat âşıklar irticalen seçilen konu üzerine irticalen kullandıkları ezgileri ya öğrendikleri, ya da geliştirdikleri ritim kalıpları üzerinden hareket ederek icra ederler. $\mathrm{Bu}$ esnada öğrendikleri ezgilerin de seyrinin değişeceğini göz ardı etmemek gerekir.

Halk ezgilerinin günümüz makam müziği nazariyatına göre bire bir karş1lık bulmadığı birçok kez dile getirilmiştir (Öztürk, 2009: 137). Halk müziği eserleri içerisinde kullanılan perdeler herhangi bir kuram çerçevesinde şekillenmediklerinden ezgilerle bütünleşen perde yapılarının bir dizisi olduğu varsayılabilir. Türkü yapıcılara bakıldığında ne bir kuram, ne bir perde, ne de bir makam üzerinden hareket ederler. İrticalen yapıldıklarından bilmedikleri bu terimler karşısında ozan veya âşık yalnız sahip oldukları bilgi ve birikimden hareketle yenilebilir ya da geliştirilebilir ezgiler meydana getirir. Ezgiler geleneğin devamı olabileceği gibi farklı yaklaşımları da ihtiva edebilir.

\subsection{Halk Ezgilerinde Ayaklar ve Eksiklikleri}

Ayak ve makam konusuna uygun örnekler incelendiğinde tanımlanmamış ayaklarla birlikte cinslerin olduğu tespit edilmiştir. Bununla birlikte yalnız makama uygun sekiz sesli örnekler alındığında bazı perdelerde yapılan geçici değişikliklerin yanı sıra iki, üç, dört, beş, altı ya da yedi perdeli örnekler göz ardı edildiği görülmüştür $\mathrm{Bu}$ doğrultuda daha önce ortak görüşten hareketle belirlenmiş on yedi ayak üzerinden incelemelere başlanılmıştır.

İlk olarak edebiyat alanında da tanımı bulunan maya ayağı örnekleri incelendiğinde perdeler açısından hüseyni beşlisi ile benzer olduğu tespit edilmiştir. Bu ayak yalnız belirlenen perdeler ile sınırlandırıldığından bu perdeler dışında kalanları ve karar perdeleri farklı olanları için herhangi bir tanımlama yapılmamıştır. Cinsler açısından bakıldığında ise hepsinin olmasa da bazılarının tanımlanmış olduğu görülmektedir. Bunlar dışında karar perdeleri farklı olanlar için de herhangi bir tanımlamanın yapılmadığı görülmüştür.

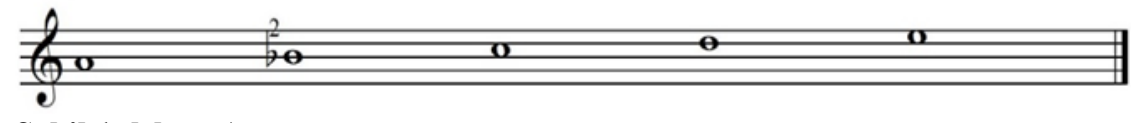

Şekil 1. Maya Ayağı. 
Hüseyni ayağı veya Divan makam dizisi (Ekici, 2009: 35) olarak ele alınan örnekler incelendiğinde ise perdeler açısından Hüseyni, Muhayyer, Gülizar ve Tahir makamları ile benzer olduğu görülmektedir. Fakat Hüseyni ayağı için inici durumda alınan fa\#3 perdesi çıkıcı durumda natürel olmaktadır. Bu durumda yalnız fa perdesi için diyez ya da natürel alanlar için herhangi bir ayak adı verilmemiştir. Bunlar dişında sib2 perdesi yerine si veya sib3 perdeleri ile birlikte karar perdeleri farklı olanlar için de herhangi bir tanım bulunmamaktadır.

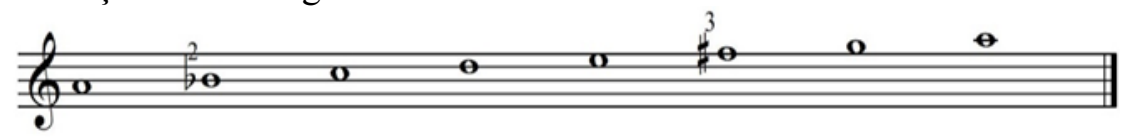

Şekil 2. Hüseyni Ayağı.

Engin hüseyni ayağı olarak ele alınan örnekler incelendiğinde perdeler açısından tıpkı Hüseyni, Muhayyer, Gülizar ve Tahir makamları ile benzerdir. Hüseyni makamı ile benzer olan engin hüseyni ayağı için inici durumda alınan fa\#3 perdesi çıkıcı durumda natürel olmanın yanı sıra çıkıcı yönde la-sib2-do-re (uşşak dörtlüsü) perdeleri ile genişlemektedir. Tıpkı hüseyni ayağında olduğu gibi yalnız fa perdesi için diyez ya da natürel alanlar için herhangi bir ayak adı olmadığı gibi bazı eserlerin inici ya da her iki yönde genişlediği tespit edilmiştir. Bunlar dışında sib2 perdesi yerine si veya sib3 perdeleri ile birlikte karar perdeleri farklı olanlar için de herhangi bir tanım olmadığı gibi inici ya da çıkıcı yönde genişlemenin belli bir sabitlikte olmayıp farklı perdeleri kullandığı görülmektedir.

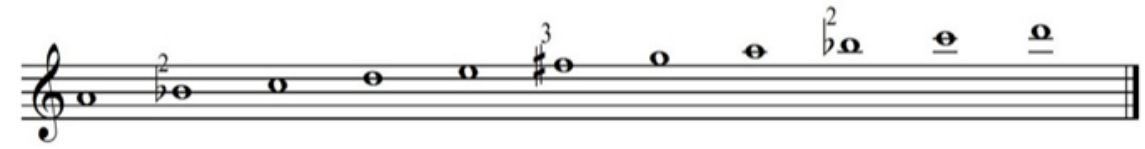

Şekil.3 Engin Hüseyni Ayağ1.

Garip ayağı olarak ele alınan örnekler incelendiğinde perdeler açısından Humayun makamı ile benzer olduğu görülmektedir. Garip ayağında fa\# ve sol\# perdeleri alanlar için herhangi bir ayak adı verilmemiştir. Bunlar dişında karar perdeleri, perde sayıları farklı olanlar ve inici yönde genişleme perdelerine sahip örnekler için herhangi bir tanımlama bulunmamaktadır.

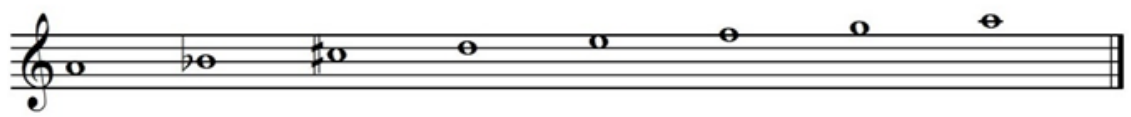

Şekil 4. Garip Ayağı.

Âşık Kerem'e ait olduğu düşünülen (Özbek, 1998: 111) ve Kerem ya da Engin Kerem ayağı olarak ele alınan örnekler incelendiğinde perdeler açısından Karcığar ve Basit Suzinak makamı ile benzer olduğu görülmektedir. Bunun dışında Uşşak, Bayati, Hüseyni, Muhayyer, Neva makamlarına karşılık bulmaktadır. Tatvan makam dizisi (Ekici, 2009: 37) olarak adlandırılan bu iki ayakta, karar 
perdeleri farklı olanlar ve si natürel perdesi alanların yanı sıra çıkıcı yönde genişlemeye sahip örnekler için herhangi bir tanımlama bulunmamaktadır. Bunun dışında Kesik Kerem Ayağına uygun örnekler bulunamamıştır. Fakat bu ayağa benzer iki örnek tespit edilmiş olsa da tanımlanmış diziye uygun kırık hava mevcut değildir. Örneklerden birinin ikinci ve altıncı perdesinde geçici olarak değiştirici aldığı tespit edilmiştir. Bu ayak çok dikkatli incelendiğinde sol perdesi ana karar perdesi gibi durmaktadır.

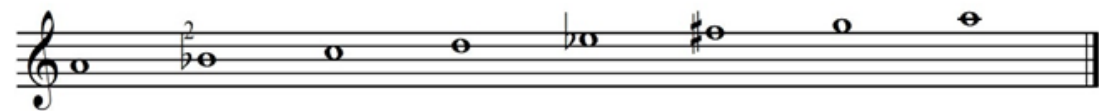

Şekil 5. Kerem Ayağı.

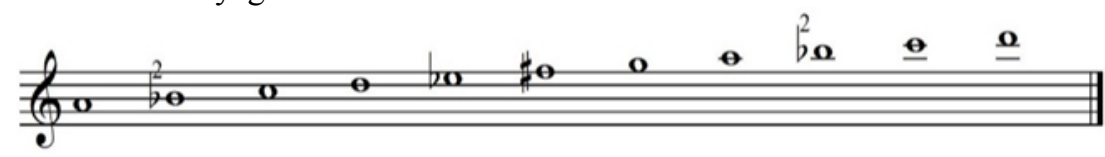

Şekil 6. Engin Kerem Ayağı.

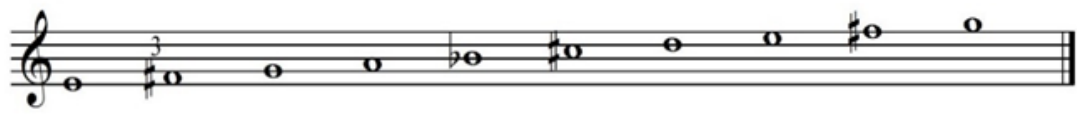

Şekil. 7. Kesik Kerem Ayağ1.

İbrahim ayağı tıpkı Engin Hüseyni ayağ 1 ile benzerlik taşımakta olup aynı zamanda uzun hava ve kırık hava icrasını bir arada taşıyan Elezber makam dizisi (Ekici, 2009: 36) özelliklerine sahiptir. Bu ayağa benzer dizilerde si ve fa perdesinin farklı perde değerleri almanın yanı sıra inici ve her iki yönde genişleyenleri için herhangi bir tanım bulunmamaktadır.

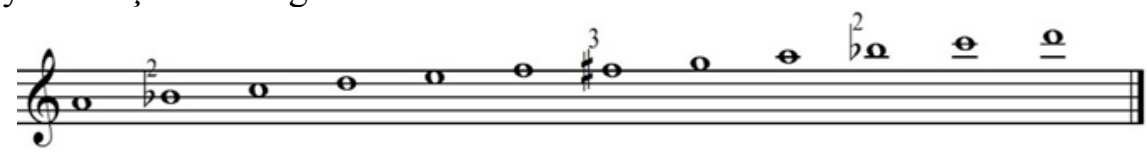

Şekil 8. İbrahim Ayağı.

Lavik ayağı Hüseyni ayağı ile benzerlik gösterse de fa perdesinin aldığ perde değeri ile farklı olduğunu göstermektedir. Bu ayağa benzer dizilerde si ve fa perdesinin farklı perde değerleri almanın yanı sıra genişleme kısımları olanlar için herhangi bir tanım bulunmamaktadır.

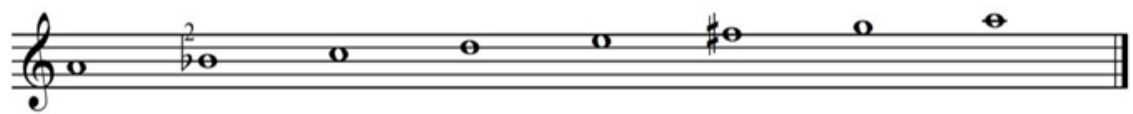

Şekil 9. Lavik Ayağı.

Türk halk müziğinin bir uzun hava türü olan Bozlak, Orta Anadolu, Doğu Anadolu'nun batısı ile Batı Anadolu'nun doğu kesimi ve Çukurova'nın bulunduğu geniş bir alanda kullanılmaktadır (Özbek, 1998: 31-32). Bozlak ayağı dizisine göre benzer bir makam yapılanması tespit edilememiştir. Fakat bu ayağa benzer ikinci, 
beşinci ya da altıncı perdesinde geçici olarak değiştirici alanlarla birlikte inici, çıkıcı veya her iki yöne genişleyen örnekler bulunmaktadır. Bununla birlikte çoğu bozlak olarak tabir edilen uzun havalarda bu dizinin dışında yapılanmalar göz ardı edilmiştir.

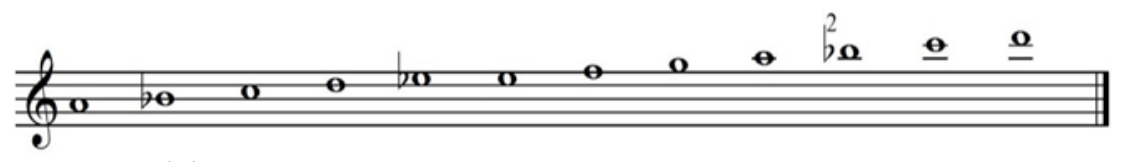

Şekil 10. Bozlak Ayağı.

Müstezat ayağı olarak ele alınan örnekler incelendiğinde perdeler açısından sol perdesi kararlı Rast, fa perdesi kararlı Acem aşiran, do perdesi kararlı olanlar ise Çargâh makamı ile benzer olduğu görülmektedir. Sol perdesi kararlı dizilerde lab, si, sib, do\#, reb2, mib fa\#3 ya da fa perdesi, do perdesi kararlı dizilerde ise mib, fa\# ya da sib perdesi alanlar için herhangi bir tanım bulunamamaktadır. Fa perdesi kararlı tanımlanmış müstezat dizi için herhangi bir örnek tespit edilememiştir. Bunlar dişında her bir müstezat ayağı için inici, çıkıcı ya da her iki yönde genişlemeye sahip diziler için ayrı bir tanımlama bulunmamaktadır.

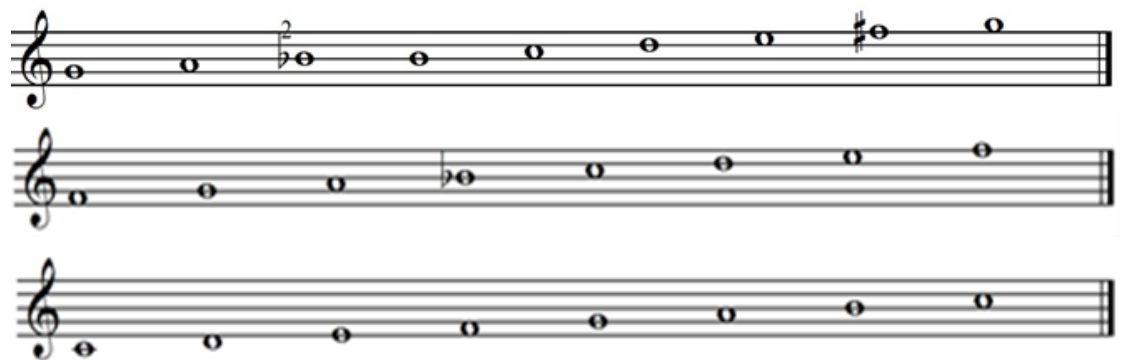

Şekil 11. Müstezat Ayă̆1.

Kalenderi ayağı olarak ele alınan örnekler incelendiğinde perdeler açısından Dügâh, Küçek ve Muhayyer Sünbüle makamına benzer olduğu görülmektedir. Dizisine göre bir yapılanma tam olarak tespit edilememiştir. Fakat bu ayağa benzer dört, beş, altı ve yedi perdeli örnekler mevcuttur. Bunun dışında dördüncü perdesinde geçici olarak değiştirici alanlarla birlikte inici yöne genişleyen örnekler bulunmaktadir.

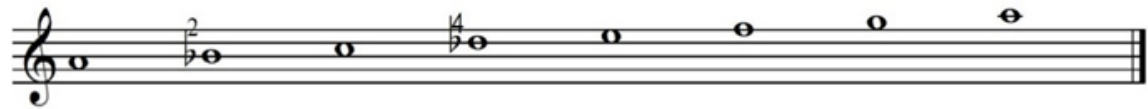

Şekil 12. Kalenderi Ayağ1.

Azeri ayağı olarak ele alınan örnekler incelendiğinde perdeler açısından makamsal bir karşılık bulunmamaktadır. Dizisine göre bir yapılanma, tam olarak tespit edilememiştir. Fakat bu ayağa benzer beş, altı ve yedi perdeli örnekler 
mevcuttur. Bunun dışında beşinci perdesinde geçici olarak değiş̧irici alanlarla birlikte inici yöne genişleyen örnekler bulunmaktadır. Bu ayak için tarif edilen perdeler dışında herhangi bir perdesinde arızi işaret alanların bazılarında makamsal tanım (Nişabur makamı gibi) olsa da tümü ayrıca bir tanım bulunmamaktadır. Ülkemizin Kuzeydoğu Anadolu ve Doğu Anadolu bölgesinin batı kesimlerinde görülen bu ayak için ayrıca makam tanımı kullanıldığı bilinmektedir (Şenel, 1991: 554).

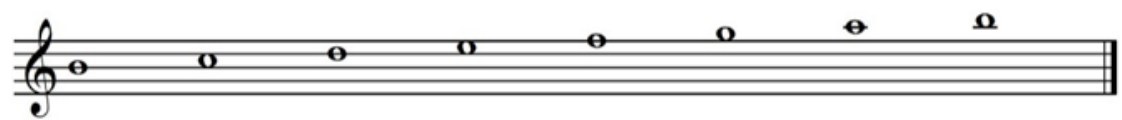

Şekil 13. Azeri Ayağı.

Yörük ayağı olarak ele alınan örnekler incelendiğinde perdeler açısından Nikriz makamına benzer olsa da tam karşılı̆̆ incelendiğinde üçüncü, dördüncü ve yedinci perdesinde geçici değiştirici almaktadır.

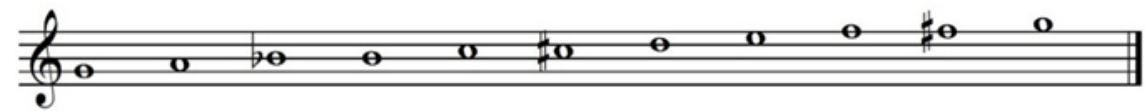

Şekil 14. Yörük Ayağı.

Misket (Karanfil) ayağı olarak ele alınan örnekler incelendiğinde perdeler açısından Rahatü'l Ervah ve Ferahnak makamına benzer olsa da tam karşılığ bulunmamaktadır. Dizi incelendiğinde do perdesi natürel olan eserler için bir tanımlama bulunmamaktadır.

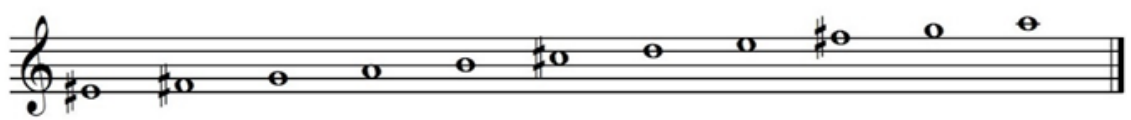

Şekil 15. Misket Ayağı.

Çubuk Uzun (Çiçekdağı) ayağı olarak ele alınan örnekler incelendiğinde perdeler açısından Lalegül, Sultani Segâh, Şerefnüma, Anbür Efşan gibi makamlara benzer olsa da tam karşıllığı bulunmamaktadır. Dizi incelendiğinde inici yönde olan genişleme kısmına ait perdelerinde geçici olarak değiştirici almaktadır.

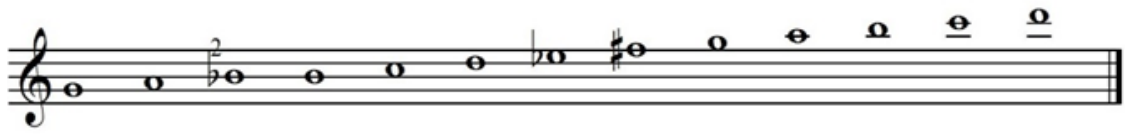

Şekil 16. Çubuk Uzun (Çiçekdağı) Ayağı.

Fidayda ayağı olarak ele alınan örnekler incelendiğinde perdeler açısından Lalegül, Sultani Segâh, Şerefnüma, Anbür efşan gibi makamlara benzer olsa da tam karşılı̆̆ bulunmamaktadır.

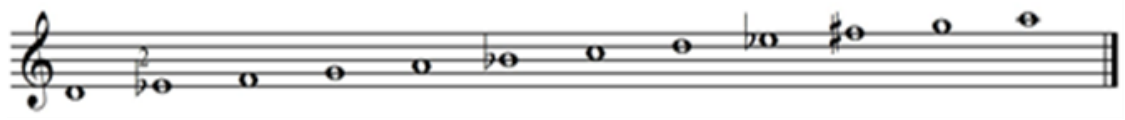


Şekil 17. Fidayda Ayağı.

\section{TARİHSEL/TERMINOLOJIK EKSIKKLIKLER VE GEREKSINIMMERE GÖRE YAPILABİLECEK BİR SINIFLANDIRMA ÖNERISII}

Perdeler açısından makamsal ezgilerden beklenen, belirli perdeler üzerinde konumlanmaya ve belli bir perdede bitişe sahip olmay1 gerektirmektedir. Perde derecelerine göre sınıflandırma yapılmasının temel nedenleri arasında ilk olarak geçici değiştiricilerin bir makam özelliği olup olmadığının tespit edilmemesidir. İkinci olarak bazı örneklerin güçlü kabul edilebilecek perdelerinin farklı derecelerde ikinci bir karar kılması ve bazılarının ise genişleme kısımları ile birlikte ana perdelerinde farklı değiştirici (Çiçekdağı ve fidayda ayağı gibi) almasından kaynaklanmaktadır. Genel olarak üç, dört, beş ve altıncı perdelerinin güçlü olduğu tespit edilen örnekler dışında asma karar olmayıp nadir de olsa özellikle uzun havalarda ikinci ve yedinci perdesinde duraklama ya da dinlenme yapan örnekler de bulunur. Bunun dişında tespit edilen perdeler üzerinde karar perdesi belirlenenlerle birlikte düzenlerinin de göz ardı edilmemesini düşündürmektedir.

"icrâ erbâbi nezdinde perde on iki makam olup Araplar bunlari 'şüdûd' [şedler/diziler], Acemler ise 'perde' ve 'makam' diye adlandırmıştır. Bunlara "meşhur devirler" de derler. Bilindiği gibi her birine, hususi bir isim de verilmiştir" (Öztürk, 2014: 9). Perdeler önem arz ettiklerinden tarihsel olarak tüm nazari çalışmalarının da başlangıç noktasını oluşturmaktadır. Bu nedenle yapılan nazari açıklamalar ve çalışmalarda ilk olarak perdenin dolayısı ile makamın önemi vurgulanmaktadir.

Makam tarihinde perde adlarında belli başlı yollar izlenilmiştir. Hatta düzenlerin de halk kültürüne çalgı pozisyonları açısından ihtiva ettiği saptanabilir (Öztürk, 2014: 43-46). Tek bir perdenin merkez olmas1 yalnız karar perdesine değil, aynı zamanda düzenin (akorduna) kurulumuna ve bu düzenler üzerinde konumlanan perdelerle birlikte makamların keşfine büyük ölçüde yardımcı olabilir. Eski nazari kuramlarında perdeler ağaz (ses verme) durumlarına göre sıra sayılarına (pençgah, şeştgah vb.) göre daha sonra ise özel isimlerle makam olarak (neva, hüseyni vb.) ifade edilmişlerdir. Bu perdeler ya da makamlar, karar perdeleri (re, mi, fa, fa\#, sol, la, hatta sib2, si, do, do\# ve re) ve düzenlerin (re, mi, fa, fa\#, sol, la, si, do ve re) aynı perde büyüklüklerini içermemesinden dolayı modlardan uzaklaşmaktadır.

Bağlama icrasında eserler; bağlamada bulunan tüm pozisyonlarda icra edilme imkânına sahip olsalar dahi, duyumsal (ifade ediliş tarzı) olarak aynı olduğunu söylemek güçtür. Düzenler; belli bir uyumu karar perdesine göre sağlar. Herhangi bir düzen içerisinde yazılmış bir eseri bozuk düzende icra etme imkânı 
olsa da tınının değiştiği çok açık bir şekilde görülecektir. Düzeni sağlayan en önemli faktörlerden biri karar sesi olup icracıyı belli perdelerde soluklanmasını (uyumlu aralıklarda) ve güzel olanı ortaya koymasına yardımcı olmaktadır. Batı müziğinde armoninin sağladığı güzellik halk müziklerinde düzen ile karşılık bulur. Bu nedenle sadece duyum ile hareket edilerek neredeyse birbirine benzer makamlar tespit edilebilir. Fakat düzenin farklı olması makamı etkileyeceğinden bu şekilde farklı düzenlere aktarılan ezgiler için yapılan duyumsal analizler bazen güvenilir bir ölçüt olmayabilir. Aşağıda motifleri birbirine benzer kararları farklı olan "Testi Doldurdum Çaydan" ve "Üç Güzel Oturmuş İskambil Oynar" adlı eserler incelendiğinde; aynı düzende dahi matematiksel hesaplamalarla bu farkl1lıkların tespit edilmesi ile sıralı perdelerin bir başka karar göçürüldüğünde olan farklılıkları kuramsal olarak ifade edilebilir.

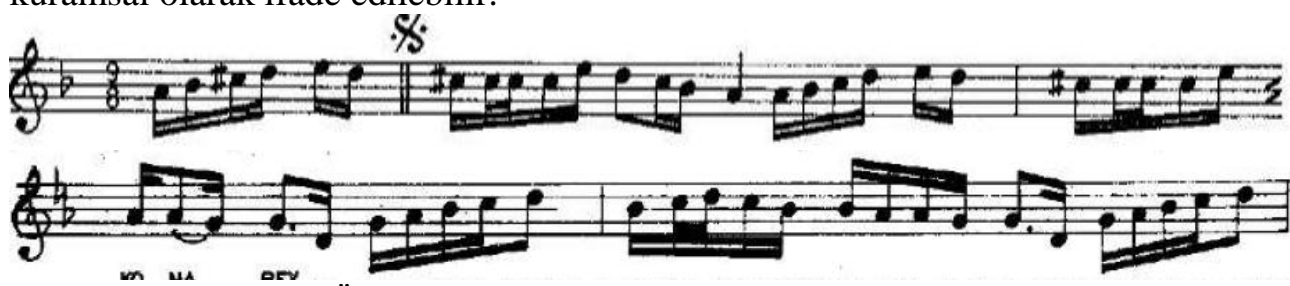

Resim 2. Motif Örneği.

Tablo 1'de motiflerin benzerliği dışında değerleri verilen aralıkların kulağın duyum yetisini rahatsız etmeyecek şekilde yakındır. Aynı düzen içerisinde iki farklı kararlı olan motif örneğinde do\# perdesi günümüz bağlamasının beş koma değerinde alınmıștır. Eğer üç koma (256 sent) değerinde alınsa idi bu aralık bölünmesi duyum olarak rahatsız etmediği ifade edilse dahi farklılı̆̆ belirgin bir biçimde ortaya çıkacaktır. Bu durumda hicaz cinsine benzer olan bu motifin hicaz cinsine benzer birden fazla bölünme şeklinin olacağını göstermektedir. Düzenlerin ilk olarak önemi bu tür motiflerle beraberinde gelen tüm cinslerin farkl1lıklarına işaret etmektir.

Tablo 1. Oranlar.

\begin{tabular}{|c|c|c|c|c|c|}
\hline \multirow[t]{2}{*}{ Perdeler } & \multicolumn{2}{|c|}{$\begin{array}{c}\text { Testi Doldurdum } \\
\text { Çaydan }\end{array}$} & \multirow[t]{2}{*}{ Perdeler } & \multicolumn{2}{|c|}{$\begin{array}{c}\text { Üç Güzel Oturmuş İskambil } \\
\text { Oynar }\end{array}$} \\
\hline & Tel Boyu & Sent & & Tel Boyu & Sent \\
\hline $\mathrm{La}$ & & & Sol & & \\
\hline & $18 / 17$ & 99 & & $35 / 33$ & 102 \\
\hline Sib & & & Lab & & \\
\hline & $4319 / 3613$ & 309 & & $6 / 5$ & 306 \\
\hline Do\# & & & $\mathrm{Si}$ & & \\
\hline & $19 / 18$ & 90 & & $18 / 17$ & 99 \\
\hline $\operatorname{Re}$ & & & Do & & \\
\hline & $9 / 8$ & 204 & & $9 / 8$ & 205 \\
\hline
\end{tabular}


Trakya Üniversitesi Sosyal Bilimler Dergisi

Aralık 2021 Cilt 23 Sayı 2 (1003-1027)

\begin{tabular}{|c|c|c|c|c|c|}
\hline $\mathrm{Mi}$ & & & $\mathrm{Re}$ & & \\
\hline & & 702 & & & 712 \\
\hline
\end{tabular}

"Makam konusunun salt dörtlü-beşli eklemlenişlerle açıklanmasındaki önemli yetersizlikleri ayrıntılı şekilde ele alıp; aslında çoğu makamın, "yapısal" eklemleniş bakımından ezgisel beşlilerde " $4+2$ ", " $2+4$ ", " $3+3$ "; sekizlilerde ise " $4+5$ ", " $5+4 ", ~ " 3+4+3$ ", " $3+3+4$ ", " $4+3+3$ " gibi seçeneklere de sahip olduğunu açık bir şekilde göstermiştir" (Oransay, 1966: 62). Bu açıklamadan hareketle tüm eserlerde mevcut bulunan ve kullanılan perdelerin bu tür eklemlerinin olabileceği ihtimali göz ardı edilmemelidir. Bu nedenle bir nazaride tüm repertuar içerisinde bulunan (yazılı eserler olarak) perdelerin bir fikir aracı olacağı ve dikkate alınması gerektiği düşündürmektedir. Böylelikle; sekizli olan makam, ayak ya da dizinin sekizlisi olmayan eserlerle bir bağlantısı olduğu yahut kullanılacak olan düzenin belirlenmesinde önemli bir ölçüt olabileceği söylenebilir. Tablo 3'de yer alan örnekler incelendiğinde perde sayılarına bakılmaksızın her biri için aynı makam denebilir. Fakat küçük bir değiştirici işaret aldığı zaman yeni fikirler öne sürülebilir.

Tablo 3. Örnekler.

\begin{tabular}{|c|c|c|c|c|c|}
\hline Üç Perdeli & Dört Perdeli & Beş Perdeli & Altı Perdeli & Yedi Perdeli & Sekiz Perdeli \\
\hline $\begin{array}{c}\text { La-sib2-do } \\
\text { Siverek Yaş } \\
\text { Üzümü } \\
\text { (Diyarbakır) }\end{array}$ & $\begin{array}{c}\text { La-sib2-do-re } \\
\text { Gidiyor } \\
\text { Musun } \\
\text { Yarim } \\
\text { (Çanakkale) }\end{array}$ & $\begin{array}{c}\text { La-sib2-do- } \\
\text { re-mi } \\
\text { Ay Doğar } \\
\text { Sini Sini } \\
\text { (Eskişehir) }\end{array}$ & $\begin{array}{l}\text { La-sib2-do- } \\
\text { re-mi-fa } \\
\text { Armut } \\
\text { Dalda Dik } \\
\text { Durur } \\
\text { (Sakarya) } \\
\end{array}$ & $\begin{array}{l}\text { La-sib2-do- } \\
\text { re-mi-fa-sol } \\
\text { Dağdan } \\
\text { Keserler } \\
\text { Meşeyi } \\
\text { (Eskişehir) } \\
\end{array}$ & $\begin{array}{c}\text { La-sib2-do-re- } \\
\text { mi-fa-sol-la } \\
\text { Çay Başına } \\
\text { Bostan Ektim } \\
\text { Yayıld } 1 \\
\text { (Antalya) } \\
\end{array}$ \\
\hline \multirow[t]{2}{*}{$\begin{array}{c}\text { Do-re-mi } \\
\text { Evlerinin } \\
\text { Önleri Sarı } \\
\text { Karınca } \\
\text { (Balıkesir) } \\
\end{array}$} & $\begin{array}{l}\text { Do-re-mi-fa } \\
\text { Elinde Süt } \\
\text { Küleği } \\
\text { (Kayseri) }\end{array}$ & $\begin{array}{c}\text { Do-re-mi-fa- } \\
\text { sol } \\
\text { Hambar Alt1 } \\
\text { Kum Alt1 } \\
\text { (Balıkesir) }\end{array}$ & $\begin{array}{l}\text { Do-re-mi- } \\
\text { fa-sol-la } \\
\text { Mendili } \\
\text { Astım Tele } \\
\text { (Bilecik) } \\
\end{array}$ & & $\begin{array}{c}\text { Do-re-mi-fa- } \\
\text { sol-la-si-do } \\
\text { Taşköprü } \\
\text { Zeybeği } \\
\text { (Kastamonu) }\end{array}$ \\
\hline & $\begin{array}{l}\text { Sol-la-si-do } \\
\text { Mavi Çuha } \\
\text { Giymiş } \\
\text { Konakta } \\
\text { Gezer } \\
\text { (Tokat) }\end{array}$ & $\begin{array}{c}\text { Sol-la-si-do- } \\
\text { re } \\
\text { Gelin Çıkma } \\
\text { Kiraza } \\
\text { (Artvin) }\end{array}$ & $\begin{array}{l}\text { Sol-la-si-do- } \\
\text { re-mi } \\
\text { Vişne Dalı } \\
\text { Eğilmiş } \\
\text { (Balıkesir) }\end{array}$ & $\begin{array}{l}\text { Sol-la-si-do- } \\
\text { re-mi-fa } \\
\text { Denizde } \\
\text { Urganim Var } \\
\text { (Bursa) }\end{array}$ & $\begin{array}{l}\text { Sol-la-si-do- } \\
\text { re-mi-fa-sol } \\
\text { Sıra Sıra } \\
\text { Siniler } \\
\text { (Çanakkale) }\end{array}$ \\
\hline
\end{tabular}

Halk ezgileri örnekleri üzerinden yapılan incelemelerde; dikkat çeken yapıların başında karar sesi büyük bir önem arz etmektir. Karar sesinin farklı olmasından dolayı ikinci yapının düzen ve akortları üzerinden hareket ettiği tespit edilmiştir. Örneğin Antalya Türküsü olan "Çekemedim Akça Kızın Göçünü” adlı eser do kararında çalınmak istendiğinde akort değişikliğini duyumsal olarak ihtiyaç 
duyacaktır. Bu nedenle bu şekilde icra edilen do kararlı eserler yahut sol kararlı eserler aynı düzenin makamları olarak ayrıca tartışılması gereken bir konu haline gelecektir.

Eserler, sahip oldukları düzenin akort yardımı ile tını yahut renklerini kullanılan tavırla şekillendirmektedir. Bu tavırlar yöresel olmanın yanı sıra kişisel olarak da ayrı bir özellik taşımaktadır. Düzenlerle şekillenen eserlerde aynı perde büyüklüklerine sahip olan makam, ayak ya da dizi perdelerinin büyüklük dereceleri, yapılan akort ile farkl11ıklar gösterecektir. Bu durumda kulak duyumsal olarak rahatsızlık vermese de yapılan düzen ya da akorttan dolayı tınıların buna müsaade etmeyeceği görülecektir. Bu nedenle yapılan düzene göre makam, ayak ya da dizi farklılıklar ihtiva edecektir. Böylelikle aynı perde büyüklüklerine sahip makam, ayak ya da diziler kendi içerisinde bulunan cinslerin büyüklüklerinin farklı olmasına neden olacaktır. Bunun yanı sıra hiç düzen değiştirilmeden eserin sahip olduğu akort üzerinden de hareket edilse dahi makam, ayak ya da dizilerin perde büyüklüklerinde farkl1lıklar olabilir. Kısacası la üzerinden bozuk düzende akort edilen ve hüseyni olarak tasarlanan bir makamın sol ya da re perdesi üzerinden aynı akort ile çalındığında oluşan tını değişikliği duyum açısından fark edilecektir. Bunun temel nedeni armonikler olup her perdenin temel bir ses gibi hareket etmesinden dolayı düzen ile birlikte yapılan akordu etkili kılmaktadır. Armonikleri harekete geçiren ise yöreye özgü kullanılan (tezeneli ya da tezenesiz) tavırlardır. Fakat aynı düzen içerisinde farklı akort yöntemleri kullanılan eserlerin rahatsız etmediği de görülebilir. $\mathrm{Bu}$ şekilde büyüklükler sahip tüm perdeler ayrıca tartışılması gereken bir konu olarak durmaktadır. Çünkü karar perdesi farklı olanın aynı makam ile ifade edilmesinin doğru olup olmadığg şed makamlar açısından günümüzde tartışmalı olduğu ortadır (Harmanc1, 2013: 27-32). Genel farkl11ık ise büyüklükleri aynı olan makamların seyrinin farklı olmasının makamı farklı kıldığıdır.

Ezgiler bağlı bulundukları merkez olan karar etrafında hem inici, hem çıkıcı hem de her iki yönde genişlemektedir. Karar perdelerinin, düzenin ve akortların farklı olması her bir perdeyi yapılan icraya göre merkez kılabileceğinden dolayı perdelerin önemli olduğunu göstermektedir. $\mathrm{Bu}$ durumda perdeler ve ezgiler içerisinde kullanılan her bir perdenin de önemi ortaya çıkacağından karar perdesinden itibaren her bir perde sira sayisal olarak derecelendirilebilecektir. Bu perdelerin yalnız birinden yapılacak bir değişiklik duyumsal etkiyi etkileyeceğinden hangi perde derecesinde değişiklik olduğu tespit edilebilecektir. Böylelikle perdeler derece özelliği aldığından; yapılacak değişikliklerin her birinde bu özellikten yararlanılabilecektir.

Eserlerde kullanılan perdelerin her biri sıralı bir şekilde ele alındığında bir başka eserin karar perdesi olabileceği gibi güçlü perdesi de olabilir. Bu yönü ile modal bir özellik göstermiş olsa da modal müzik demek mümkün olmamaktadır. 
Bu nedenle söz vurgularının bunu belirleyici özellik kılacağı düşünülebilir. Fakat sözsüz eserlerde dans figürlerinin belirleyici olacağı görülecektir. Bu durumda aynı perdeleri kullanan eserlerde asma kararlı eserler göz ardı edildiğinde ilk değişikliğin güçlü perdesinde, ikinci değişikliğin ise genişleme kısımlarının yönlerinde ve genişleme kısımlarında kullanılan perdelerde olacaktır. $\mathrm{Bu}$ açıdan tespit edilen eksikliklerden ayak, makam ve diziden hareketle bir yöntem belirlenmiştir. İzlenilen yol içerisinde birinci olarak mevcut müzik yazıları tercih edilmiştir. Perdelerin bir şekilde uyarlanarak belli işaretlemelerle perde yüksekliklerinin ifade edilmesi birçok açıdan yetersiz olmasına rağmen, bilimsel çalışma için vazgeçilmez olan müziğin bir kaydını verir (Haydon, 1946: 221). İkinci olarak ise icra örneklemleri ele alınmıştır. Geleneksel metot içerisinde ustaçırak ilişkisi ile yapılan ezgisel hareketlerde kullanılan dinamikler (hatta perde ve düzenler) değişken olsa da mukayeseler için olumlu yöntemleri ihtiva eder.

On sekizinci yüzyıldan itibaren karar perdesinin önemli bir unsur olduğu görülür (Öztürk, 2014: 9). Karar perdesini güçlü kılan esasında aynı karar perdesinin eserlerde oktavı ya da beşlisinin birlikte kullanılması ile tetiklenen ve nazariyatçıların da bir konusu olan uyum meselesidir. Bu nedenle eserlerde karar perdelerine göre ardından gelen perdeler çıkıcı olarak sıralanmıştır. Ezginin başlangıç ses perdesinin hareketi ne olursa olsun son noktası karar perdesi olduğundan karar perdesi en nihai nokta olarak kabul edilmiştir. Perde sayısına göre sekizli (oktavı) olmayan örneklerde genişleme pest tarafa, olanlarda ise hem pest, hem tiz, hem de her iki yönde genişleyen örnekleri tespit edilmiştir. Perde sayısına göre perde derecelerinde geçici değiştirici alanlar ayrıca sınıflandırılmıştır. Tüm bu işlemler sonunda eserler tek-tipli ezgi örnekleri, İki-tipli ezgi örnekleri, çok-tipli ezgi örnekleri ve herhangi bir ezgi örneği olup farklı perdeleri karar kılanlar olarak dört ana başlık tespit edilmiştir. Bunlar dışında ayrıca yeden perdelerinde de değiştirici alan örnekler de mevcuttur.

Tek tipli ezgi örnekleri karar perdesi üzerine ardışık olarak sıralan perdelerin sabit (herhangi bir perdesinde yeniden bir değiştirici almayanları) olup olmamasına göre değerlendirilmeye alınmıştır. Sabit olduğu tespit edilen örnekler tek tipli ezgi örnekleri altında (genişleme kısımları ayrıca yazılarak) incelenmiştir.

İki tipli ezgi örnekleri karar perdesi üzerine ardışık olarak sıralan perdelerin herhangi bir perdesinde değiştirici olup olmamasına göre değerlendirilmiştir. Bazı makamlar içerisinde makama özgü olmayan perdelerin kullanımı makamı değiştirmeyeceği düşünülmektedir (Karadeniz, 1984: 98). Buna rağmen bazı perdeler arasında perdelerin bulunduğunu ve bu perdelerin makamın havasını değiştireceği on beşinci yüzyıl sonlarında Kadızade Tirevî tarafından ifade edilmiştir (Uygun, 1990: 32). Bu açıdan ele alındığında perdeler arasında herhangi bir değişim ya da değiştirici kullanmanın makamın kimliğini değiştirmediği 
düşünülse de bu makamın esasının hangi makam teşkil ettiğini söylemek güç olacaktır. Fakat tam perde arasında bulunan perdelerin, on sekizinci yüzyılda açıklanması gereken perdeler olarak makam konusunda ayrı bir önem arz ettiği ortadadır. Bu nedenle nazariyeler arası farklılıkların konuyu karmaşıklaştırdığı ve güvenirliği sorgulayıcı hale getirmektedir.

İki tipli ezgi örnekleri karar perdesi üzerine ardışık olarak sıralan perdelerin herhangi iki veya daha fazla perdesinde değiştirici olup olmamasına göre incelenir. Farklı perdelerde karar verenler ise günümüz terminolojisine göre asma ya da askı kararlı olarak incelenir. Bu tür kararlı eserlerin dahi tek, iki ve çok tipli ezgi örneklerinin özelliklerini içerdiği tespit edilmiştir.

\section{SONUC ve ÖNERILER}

Ayaklar konusunda tanımlamalara bakıldığında; isimlendirmelerin karar perdelerine göre ve dizinin ilk dört perdesinden hareketle yapıldığı görülmektedir. $\mathrm{Bu}$ nedenle sekiz perdeli bir diziden ziyade sayıca fazla olan dört, beş, altı ve yedi perdeli dizilere göre isimlendirilmiş gibi durmakta olup sekiz perdeli olarak gösterilen dizi söz konusu ayağın yalnız havasını yansıtmaktadır. Bazı ayak örnekleri için oktavını tamamlayan eserler yok denecek kadar azdır. Bazıları ise bölgelerden ya da eserlerden yola çıkılarak isimlendirilmiş gibi durmaktadır.

Halk ezgilerinin bazılarını basit, şed (göçürülmüş), ya da birleşik makam türleri içerisine yerleştirmek mümkündür. Perde sayıları göz ardı edilmesine rağmen aynı perde dizilerine sahip eserlerin seyir, güçlü, yeden perdesi ve genişleme kısımlarının yapılan farklılıklar ile halk ezgilerini tanımlanmış makam dizilerinden uzaklaştırmaktadır. Bunun dışında bozlak ayağı gibi tam olarak makamsal tanımlanamayan diziler gibi bazı eserlerin genişleme kısımları tıpkı bu ayakta olduğu farklı cinslerle yapılanmaktadır.

İncelemeler esnasında tespit edilenler; sekiz perdeli (oktavı tamamlamayan diziler) olmayan iki, üç, dört, beş, altı, yedi perdeli diziler, yeden perdesi olan ya da olmayanlar, güçlü perdesi değişenler ya da olmayanlar (özellikle üç, dört ve beş perdeli örnekler için), yalnız inici yönde genişleyenler (özellikle üç, dört, beş, altı ve yedi perdeli örnekler için), yalnız sekiz perdeli olanlar ile birlikte genişleme kısmında inici, çıkıcı ya da her iki yönde genişleyenler, belirli bir sayıda perde sahip olup kararı farklı olanlar, belirli bir sayıda perde sahip olup kararı iki, üç, dört veya beşinci perdesi olanlar (asma kararlı örnekler), sekiz perdeli olup oktavi farklı olan ve belirli perdelerinde geçici olarak değiştirici alan örnekler ile karşılaşılmıştır.

Halk müziğinde düzenler kişi ya da yöreye özgü olarak değişiklik göstermektedir. $\mathrm{Bu}$ âşık ya da ozanın insiyatifi dışında beğeni ile kalıplaşmış ve yörenin tavrına, üslubuna, oyununa göre şekillenebilir. Bir anlamda düzen; tıpkı türkülerde olduğu gibi başka yörelere ya benzer, ya da tıpatıp uygunluk sağlayabilecek kalıpları alabilir. Böylelikle başka yörelerce benimsenmiş ya da 
kullanılmış olup olmadığı tespit edilebilir. Bu durum; halk ezgilerinin taşınırken düzenini de beraberinde getirdiğini düşündürmektedir. Düzenler ezgilerin dolayısı ile akordunu, tavrı ile beraberinde taşıyabilir. Burada belirleyici olan hafiza olduğundan uygunluk gösterebilecek farklı akortların, taşınan ezgilerle birlikte büyüklük olarak perdelerini etkileyerek aynı makam benzerlerini oluşturabileceği ihtimalidir. Halk ezgilerinde karar ve düzen, perde büyüklüklerini dolayısı ile perdenin önemini ortaya koyacaktır. Aynı aralık kalıplarına sahip perdelerin çeşitli büyüklüklerle ifade edilmesinin ve aktarım esnasında karar perdesinin değişmesinin ya da göçürülmüş olmasının temel nedenin bu olduğu sonucu çıkarılabilir. $\mathrm{Bu}$ tür benzerliklerle saptanan makam takımları (aileleri) ya da cinsleri, makamları sınıflandırma da belirleyici rol olacağı gibi düzene ait makamların olup olmadığı hakkında fikir sahibi olmamızı sağlayabilir.

Halk ezgileri kişisel olmasının yanı sıra yöreye özgü özel sıralı perde yapılanmasına sahiptir. Bu sıralı perdeler yöre özellikleri dışında kişisel becerilerle farklı ifadelere sahip olabilir. Bu nedenle bugüne kadar yapılan tanımlamalar dışında herhangi bir terminolojik tanımlama yapılamamaktadır. Fakat tespit edilen eksiklikler üzerinde hareketle halk ezgilerini sınıflandırmak için ilk olarak karar perdesinin belirlenmesi öncelik arz etmektedir. Karar perdesi belirlenen örnekler perde sayılarına göre perde dereceleri ile sınıflandırılmalıdır. Perde dereceleri ile yapılan sınıflandırılmada geçici olarak değiştirici alan örnekler belirlenmelidir. $\mathrm{Bu}$ doğrultuda iki ana ilke doğrultusunda sıralı perdeler sınıflandırılabilecektir. Her bir örnek sahip olduğu ezgisel hareketlilikle; karar yahut perdelerine göre belli bir bölgeyi işaret etmediğinden bu iki temel ilke altında toplanan diziler için ortak bir dil kullanılmış olacaktır. İkinci olarak eserin düzen ve akordu tespit edilmelidir. Bunun dışında makam müzikleri birer perde müziği olduğundan perdelerin çizdiği ezgilerin birer perde müziği olduğunu unutmamak gerekir. Bu yüzden makam ve ayak konusunun yetersiz olduğu noktalarda her bir perdenin hem sayısal, hem de duyumsal olarak doğru tespiti yapılacak olan düzen ile belirlenecektir.

Halk müziği ana çalgılarından olan bağlama üzerinde yapılanan ve bazı eserlerin içerdiği düzen (misket, müstezat vb.) başka bir makam ailesine yakınlığ 1 olsa da içerdiği perdeler açısından hem konumları, hem de sayısal büyüklükleri açısında bir başka makama işaret edebilir. Bu tür düzenleri yakın makam ailelerine aktarılması mümkün olsa da havanın ve tınının değişeceğini her icracı bilir. Makam müziğinde bunlar bir terkip, şube ya da şedd olarak da değerlendirilebilir. Fakat bu eserlerin bu bilgi ya da birikimle yapıldığını iddia etmek mümkün olmamaktadır. $\mathrm{Bu}$ nedenle tüm eserler kendi içinde ayrıca sıra perde sayılarına göre sinıflandırılabilecektir. 


\section{KAYNAKÇA}

Arel, S. (1991). Türk Mûsıkîsi Nazariyatı Dersleri. Ed: Onur Akdoğu. Ankara: Kültür Bakanlığı Yayınları.

Behar. C. (2019). Aşk Olmayınca Meşk Olmaz, Geleneksel Osmanlı / Türk Müziğinde Öğretim ve İntikal, İstanbul: Yapı Kredi Yayınları.

Deniz, Ü. (2018). "Rauf Yektâ Bey’in Türk Halk Müziği Hakkındaki Görüşleri”, The Journal of Academic Social Science Studies. 71, 249-276.

Eke, M. (2016). "Türk Halk Müziği Ezgilerindeki Motifler ve İşlevleri”. Karadeniz, Say1:32, 37-47. İstanbul.

Ezgi, S. 1940. (1940), Nazarî Amelî Türk Mûsıkîsi IV., Hüsnitabiat Matbaası,

Gazimihal, M.R. (2006). Anadolu Türküleri ve Musıki İstıkbalimiz (çev. Prof. M. S. E. - A. Ş. A.). İstanbul: Ötüken Neşriyat.

Güray, C. (2017). "Türk Halk Müziği Repertuarının Tespiti ve İcrasi Açısından Darü'l Elhan Derlemelerine Yansıyan 'Makam' Algısının Tartısılması”, Darülelhan Sempozyumu, İstanbul.

Haydon, G. (1946). "Introduction to Musicology", USA: Prentice-Hall.

Harmancı, A. B. İ. (2013), "Şed Makam Mı Şed İcrâ Mı”, Rast Dergisi, Cilt1, Sayı 1, 22-77.

Kaçar, G. Y. (2008). “Türk Mûsikîsinde Makam”, İstem, Yı1:6, Sayı:11, s.145 158.

Karabulut, M. (1995). Âşıłklık Geleneğinde Söz ve Ezgi. (Yayınlanmamış Yüksek Lisans Tezi). Kayseri: Erciyes Üniversitesi Sosyal Bilimler Enstitüsü. Yayınları.

Karadeniz, E. (1984). Türk Musikisinin Nazariye ve Esasları. Ankara: İş Bankası

Karaduman, İ. (2014). "Geleneksel Türk Halk Müziğinde Makâm Kavramının Kullanılmasına Edvâr Geleneği Açısından Bir Yaklaşım”, Turkish Studies, Volume 9/8 Summer, s. 587-601.

Kaygusuz, N. (2006). Muallim İsmail Hakkı Bey ve musiki tekamül dersleri: Muallim İsmail Hakkı Bey'in hayatı, sanatçı kişiliği, musiki tekamül dersleri, İTÜ Vakfı Yayınları, İstanbul.

Kolukırık, K. (2012). "Batı Anadolu'da 1925 Yılında Derlenmiş Zeybekleri İçeren "Yurdumuzun Nagmeleri" Adlı Kitap Üzerine Bir İnceleme”, C.Ü. ilahiyat Fakültesi Dergisi, Cilt: XVI, Sayı: 1 Sayfa: 787-803.

Kolukırı, K. (2014). "Osmanlı Devleti'nde İlk Resmî Konservatuvar Olan Dârülelhanda Derleme ve Yayım Faaliyetleri", Türkiyat Araştırmaları Dergisi, Sayı 35, 479-498.

Kutluğ, Y. F. (2000). "Türk Musikisinde Makamlar İnceleme”, Yap1 Kredi Yayınları, İstanbul. Yayınları.

Oransay, G. (1966). Die Melodische Linie und Der Begriff Makam. Ankara: Küğ

Özbek, M. (1994). Folklor ve Türkülerimiz. İstanbul: Ötügen Yayınları.

Özbek, M. (1998). Türk Halk Musikisi El Kitabı 1 Terimler Sözlüğü, Atatürk Kültür Merkezi Yayınları, Ankara. 
Özdemir, U. (2019). "Notanın otoritesi, otoritenin notası: Türkiye'de nota-merkezli resmî halk müziğinin yapısökümü”, Rast Dergisi, Vol: 7, No:2, 2122-2148.

Öztürk, O. M. (2009). “Geleneksel Müzikte Pratik ve Teori İlişkisi: Kütahya Yerel Müziğinin Bir "Temsilci”si ve "Uygulayıcı"sı Olarak Hisarlı Ahmet”, Hisarlı Ahmet ve Kütahya Türküleri Sempozyumu, Kütahya.

Öztürk, O. M. (2014a ). "Makam Müziğinde Ezgi Ve Makam İlişkisinin Analizi Ve Yorumlanması Açısından Yeni Bir Yaklaşım: Perde Düzenleri Ve Makamsal Ezgi Çekirdekleri”. (Yayınlanmamış Doktora Tezi). İstanbul: İTÜ Sosyal Bilimler Enstitüsü.

Öztürk, O. M. (2014b). "Makam, Âvâze, Şûbe Ve Terkip: Osmanlı Musiki

Nazariyatında Pisagorcu "Kürelerin Uyumu/Musikisi Anlayışının Temsili", Rast Dergisi, Vol: 2, No:1, 1-49.

Sarısözen, M. (1944), “İki Sesli Halk Türküsü”, Ülkü Milli Kültür Dergisi, Ankara.

Sipos, J. (2000), In The Wake of Bartok in Anatolia, European

Folklore Institute, Macaristan.

Şenel, S. (1991). “Aşık Musikisi”. Türkiye Diyanet Vakfı İslam Ansiklopedisi. (Cilt: 3, Sayfa: 553-556). Ankara: Türkiye Diyanet Vakfi.

Sümbüllü, H. T (2015) “Aşıklık Geleneğinde Kullanılan "Makam” Kavramı Üzerine Müzikal Bir Değerlendirme”. Rast Dergisi. Vol:3, No:2,828-836.

Tutu, S. B. (2012). "Türkiye Sahası Aşıklık Geleneğinde Bir Terim Tartışması: Makam”. Türkiye Sosyal Araştırmalar Dergisi. Sayı: 163, Sayfa: 93-100

Uygun, M. N. (1990). Kadızâde Tirevî ve musiki risâlesi. (Yüksek Lisans tezi). İstanbul: Marmara Üniversitesi.

Yarman, O. (2009), "Makam Kuyumcuları”, Saz ve Söz İnternet Dergisi, say1 7.

Yavuz E. D.-Tahtaişleyen N.-Önder E. (2020). Fonograf Alanda Erken Dönem Karşılaştırmalı Müzikoloji Çalışmaları, Berceste Yayınları, İstanbul.

Yener, S. (1991). Bağlama Öğretim Metodu III, Trabzon: Karadeniz Gazetecilik ve Matbaa Sanayi.

Yönetken, H.B. (1982). “Türkiyede Müzik Folklorü Çalışmaları”, Musiki Mecmuas1, Y11. 35, No. 398, İstanbul: Atalay Matbaas1.

Zeren, A. (2003). Müzik Sorunlarımız Üzerine Araştırmalar. İstanbul: Pan Yayınc1lık. 

December 2021 Volume 23 Issue 2 (1003-1027) 